theme of using China's spiritual inheritance in Christian education, has been published and has gone into a second edition. From 1932 to 1934 he was at Davis and Elkins College, where he taught a course in the outlines of the History of China.

Mr. John Carter Vincent, Chief, Division of Chinese Affairs, Department of State, has continued his active career throughout the war years. The positions he has held during this period are: consul at Shanghai August 10, 1940 to December 7, 1941 ; first secretary at Nanking, June 3, 1941; counselor of embassy at Nanking (detailed to Chungking), March 17, 1942; counselor of embassy at Chungking July 1, 1942; assigned to the Department December 15, 1942; assistant chief, Division of Far Eastern Affairs, August 21, 1943; detailed to the Office of Foreign Economic Administration as special assistant to the administrator October 25, 1943 to February 25, 1944; liaison officer with the Office of Foreign Economic Administration, first session of the Council, United Nations Relief and Rehabilitation Administration, Atlantic City, N. J., 1943; chief, Division of Chinese Affairs, January 15, 1944.

\title{
Paul Pelliot
}

Professor Paul Pelliot, one of the greatest sinologues of all time, died in Paris cn October 29, 1945.

Professor Pelliot was bom in 1878. He originally intended that his career should be one of official service, but his interests in history and linguistics soon directed him to a career of productive scholarship which covered more than forty years. From 1901 to 1906 he served as professor at l'Ecole française d'Extrême Orient in Hanoi; from 1906 to 1908 he conducted an exploratory mission in Central Asia, during which he recovered great quantities of valuable material from the Tun-huang grottos. He served as professor at the College de France from 1911, and as curator of the Ennery Museum, Paris, from 1934. During the First World War he served both in France and in the Dardanelles. He was awarded the Victoria Cross for taking command of a British regiment after all of its officers had been killed. During the Second World War he performed invaluable services to France and to the world of art through his work in helping to preserve French art from requisition by the Nazis. His numerous articles and reviews have exerted and will continue to exert a profound influence on the scientific study of Chinese and related civilizations. 